\title{
Energy and Performance Comparison of Microbial Fuel Cell and Conventional Aeration Treating of Wastewater
}

\author{
Tyler Huggins ${ }^{1}$, Paul H Fallgren ${ }^{1,2}$, Song Jin $^{2}$ and Zhiyong Jason Ren ${ }^{1 *}$
}

${ }^{1}$ Department of Civil Engineering, University of Colorado Denver, Denver, Colorado 80217, USA

${ }^{2}$ Advanced Environmental Technologies, Fort Collins, Colorado 80525, USA

\begin{abstract}
Microbial fuel cell (MFC) technology provides a low cost alternative to conventional aerated wastewater treatment, however, there has been little comparison between MFC and aeration treatment using real wastewater as the substrate. This study attempts to directly compare the wastewater treatment efficiency and energy consumption and generation among three reactor systems-a traditional aeration process, a simple submerged MFC configuration, and a control reactor acting similar as natural lagoons. Results showed that all three systems were able to remove $>90 \%$ of COD, but the aeration used shorter time ( 8 days) than the MFC (10 days) and control reactor ( 25 days). Compared to aeration, the MFC showed lower removal efficiency in high COD concentration, but much higher efficiency when the COD is low. Only the aeration system showed complete nitrification during the operation, reflected by completed ammonia removal and nitrate accumulation. Suspended solid measurements showed that MFC reduced sludge production by $52-82 \%$ as compared to aeration, and it also saved $100 \%$ of aeration energy. Furthermore, though not designed for high power generation, the MFC reactor showed a $0.3 \mathrm{Wh} / \mathrm{g} \mathrm{COD} / \mathrm{L}$ or $24 \mathrm{Wh} / \mathrm{m}^{3}$ (wastewater treated) net energy gain in electricity generation. These results demonstrate that MFC technology could be integrated into wastewater infrastructure to meet effluent quality and save operational cost.
\end{abstract}

Keywords: Microbial fuel cell; Wastewater treatment; Dissolved oxygen

\section{Introduction}

Traditional activated sludge or aerated lagoon wastewater treatment processes can efficiently remove organic pollutants, but operating such systems are cost and energy intensive, mainly due to the aeration and sludge treatment associated processes. The United States spends approximately $\$ 25$ billion annually on domestic wastewater treatment, and another $\$ 202$ billion is needed for improving publicly owned treatment works [1]. Wastewater treatment accounts for about $3 \%$ of the U.S. electrical energy load, which is approximately 110 Terawatt hours per year, or equivalent to 9.6 million households' annual electricity use [2]. Traditional activated sludge based treatment processes employ aerobic heterotrophic microorganisms to degrade organic matters. Such types of microbes have high metabolic kinetics, so they can process substrates faster than anaerobic bacteria, but they also require sufficient supply of oxygen and generate significant amount biomass. Aeration can amount to $45-75 \%$ of wastewater treatment plant (WWTP) energy costs, while the treatment and disposal of sludge may count up to $60 \%$ of the total operation cost.

The next generation of wastewater infrastructure should consider transforming current energy-intensive, treatment-focused processes into integrated systems that recover energy and other resources. It was estimated that the energy content embedded in wastewater is estimated about 2-4 times the energy used for its treatment, so it is possible to make wastewater treatment self-sufficient, if new technologies can recover the energy, while simultaneously achieving treatment objectives. Microbial fuel cells (MFCs) recently emerged as a novel technology to fulfill this mission because they directly convert biodegradable materials into renewable energy with minimal sludge production [3]. MFCs employ exoelectrogenic bacteria to extract electrons from organic and inorganic substrates and transfer them to the anode to the cathode, where they then combine with oxygen and protons to produce water [4]. MFCs have been shown effective in treating almost all kinds of waste streams, including municipal, brewery, agricultural, refinery, paper cycling wastewater, and even landfill leachate [5]. The power output is dependent on the biodegradability of the substrate, conversion efficiency and loading rate. For example, using similar type of MFC reactors, $261 \mathrm{~mW} / \mathrm{m}^{2}$ [6] was obtained using swine wastewater, while other studies have demonstrated that a maximum power output of $205 \mathrm{~mW} / \mathrm{m}^{2}$ [7] can be achieved using brewery wastewater and 672 $\mathrm{mW} / \mathrm{m}^{2}$ using paper recycling wastewater [8].

The advantages of MFCs in wastewater treatment mainly come from the energy saving and production and sludge minimization. The functional bacteria in MFCs are generally anaerobic or facultative microorganisms, so the operation of MFCs may not use any active aeration [9]. In addition, the cell yield of exoelectrogenic bacteria (0.07-0.16 $\mathrm{gVSS} / \mathrm{gCOD})$ was much less than the activated sludge (0.35-0.45 gVSS/gCOD), so sludge production can be significantly reduced [10]. However, most wastewater MFC studies have focused on energy production from MFCs, while very few compared the energy use/generation and sludge production between MFCs and traditional aeration based processes. Zhang et al. [11,12] recently investigated tubular MFC performance in treating municipal wastewater, by either operating them separately or submerged them in aeration tanks. The

*Corresponding author: Zhiyong Jason Ren, Department of Civil Engineering, University of Colorado Denver, Denver, Colorado 80217, USA Tel: 303-556-5287; Fax: 303-556-2368; E-mail: zhiyong.ren@ucdenver.edu; zhiyong.ren@colorado.edu

Received March 13, 2013; Accepted May 14, 2013; Published May 17, 2013

Citation: Huggins T, Fallgren PH, Jin S, Ren ZJ (2013) Energy and Performance Comparison of Microbial Fuel Cell and Conventional Aeration Treating of Wastewater. J Microb Biochem Technol S6: 002. doi:10.4172/1948-5948.S6-002

Copyright: (c) 2013 Huggins T, et al. This is an open-access article distributed under the terms of the Creative Commons Attribution License, which permits unrestricted use, distribution, and reproduction in any medium, provided the original author and source are credited 
findings demonstrate that higher COD removal (65-70\%) and power production $\left(0.015-0.024 \mathrm{KWh} / \mathrm{m}^{3}\right)$ were obtained in those separated systems, while the submerged system showed unstable performance due to biofouling and various operating conditions. Other studies showed that MFC may increase organic removal in pharmaceutical wastewater than anaerobic systems, but no energy comparison was provided [13]. In this study, we aim to provide side-by-side quantitative information in evaluating the potential energy and treatment benefits of MFCs, as compared to traditional aeration processes such as activated sludge or aerated lagoon systems. We used liter-scale reactors to quantitatively audit the power generated or consumed during the operation of an MFC, an aeration tank, and a control reactor during the treatment of wastewater. We also compared system performance in terms of COD and ammonia removal, and the concentration changes in nitrate, suspended solids and dissolved oxygen. We hope the results obtained in this study provide some quantitative proofs that MFCs can be a viable wastewater treatment technology, though performance needs to be further improved.

\section{Materials and Methods}

\section{Reactor configuration and construction}

Three reactors, including an MFC, an aeration reactor and a control reactor, were constructed using a same type of $15 \mathrm{~L}$ container. The single-chamber submerged MFC reactor was configured using graphite brush as the anode (Chemviron Carbon), and carbon cloth $(1 \% \mathrm{Pt})$ as the air-cathode (Fuel Cell Earth LLC), with no pumps or electricity consuming devices (Figure 1). The same $15 \mathrm{~L}$ container was used for the aeration reactor, with an aquarium pump air diffuser at the bottom (Figure 1). The control reactor used a same type of container, but without any aeration equipment or electrode installed (Figure 1). All reactors were operated in fed-batch mode at room temperature and exposed to the ambient air.

\section{Reactor start-up and operation}

Industrial wastewater was collected from the effluent of the primary clarifier from the Coors Wastewater Treatment Plant in Golden, Colorado. The wastewater characteristics are shown in Table 1. The

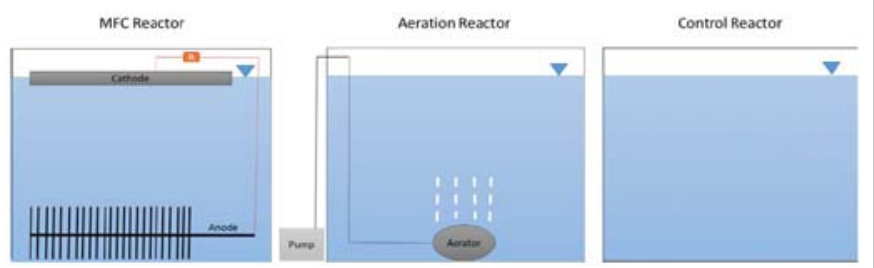

Figure 1: The reactor configurations.

\begin{tabular}{|l|l|}
\hline Parameter & Value \\
\hline $\mathrm{pH}$ & $6.9 \pm 0.1$ \\
\hline Total COD, $\mathrm{mg} / \mathrm{L}$ & $1275 \pm 72$ \\
\hline $\mathrm{NH}_{4}^{+}-\mathrm{N}, \mathrm{mg} / \mathrm{L}$ & $10 \pm 2$ \\
\hline $\mathrm{NO}_{3}{ }^{-}, \mathrm{mg} / \mathrm{L}$ & $2 \pm 2$ \\
\hline Alkalinity, $\mathrm{mg} \mathrm{CaCO}_{3} / \mathrm{L}$ & $1000 \pm 26$ \\
\hline
\end{tabular}

Table 1: Characteristics of the municipal wastewater used in the study. wastewater was used as the inoculum and sole substrate for all three reactors. No extra medium or buffer solution was added. The MFC reactor went through an initial 7 day inoculation period before the wastewater was replaced and measurements taken. All reactors were operated until $>90 \%$ COD reduction was achieved, then the wastewater was replaced for a series of three trials.

\section{Analyses and calculations}

Closed circuit voltage (V) and amps (A) were measured and recorded using a data acquisition system (Keithley Instruments, Inc. $\mathrm{OH}$ ), across an external resistance (R) of $10 \Omega$ in a time interval of 3 minutes. Power in watts $(\mathrm{W})$ was calculated from the equation $\mathrm{W}=\mathrm{V} \cdot \mathrm{A}$. Power generation or consumption was measured during a specific time measured in hours (h), expressed in watt hours (Wh), and calculated using the equation $\mathrm{Wh}=\mathrm{W} \cdot \mathrm{h}$. The wattage for the aeration pump was determined from the manufacturer's specification of $2 \mathrm{~W}$, while the wattage generated from the MFC was determined from the data acquisition system and the equation described above. Polarization curve was normalized by cathode surface area, and was determined by conducting a linear sweep voltammetry test using a potentiostat (G 300 , Gamry Instruments). Dissolved oxygen concentration was measured with a standard DO probe (DO50-GS, Hach Co.)COD, DCOD, $\mathrm{NH}_{4}{ }^{+}-\mathrm{N}$, and $\mathrm{NO}_{3}{ }^{-}$concentrations were measured with digester vials (Hach Co.), according to APHA standards. The solid retention time (SRT) was calculated based on the amount of time in days (d) each reactor was operated.

\section{Results and Discussion}

\section{Organic removal}

All 3 reactors were fed with the same wastewater with a COD concentration of $1247 \pm 64 \mathrm{mg} / \mathrm{L}$. The reactors were operated in batch mode till reaching $>90 \%$ of COD removal. While all reactors were able reach the same treatment goal, the average retention time for achieving similar treatment efficiency varied significantly (Figure 2). The MFC reactor took 15 days to reach to $90 \%$ removal, which is 10 days shorter than the control reactor without aeration, but 2 days longer than the aeration reactor. The shorter retention time for the aeration reactor is similar to the extended aeration activated sludge systems, and can be attributed to the readily available oxygen supply and rapid metabolisms of aerobic respiration [10]. The SRT of the control is around 25 days, close to traditional stabilization lagoons, which do not employ mechanical aeration and may create aerobic, anoxic and anaerobic layers of environment for different microbial community and metabolisms. The absence of mechanical aeration in the MFC reactor also provided an anoxic environment, but experienced much shorter retention time than the control. These results suggest that by providing a submerged anode and a floating cathode, the MFC configuration significantly facilitated substrate oxidation rate close to aeration operation, but without any external oxygen supply.

Such variations can also be presented by COD removal rates. As shown in Figure 3, the COD removal rates from the three systems varied significantly and changed depending on the COD concentrations. During the initial stage of operation, when the COD concentration was high, COD removal rate for the aeration reactor averaged around 291.0 $\pm 19.2 \mathrm{mg} / \mathrm{L} \cdot \mathrm{D}$, which was 3.6 times and 5 times higher than that of the MFC or control reactor treating the similar COD concentrations. 
However, when the COD concentration decreased to around 275 $\mathrm{mg} / \mathrm{L}$ or less, the removal rate for the aeration reactor decreased to an average of $12.6 \mathrm{mg} / \mathrm{L} \cdot \mathrm{D}$. This rate was similar to that of the control, but significantly less than that of the MFC reactor, which had an average COD reduction rate of $50.0 \mathrm{mg} / \mathrm{L} \cdot \mathrm{D}$. This observation may be interpreted using the different degradation natures between suspended growth systems and attached growth systems. Many studies and models showed that compared to attached growth systems, such as trickling filters, completely mixed suspended growth systems such as activate sludge were able to treat high concentrated organics more efficiently, but the effluent COD was highly depending on the solid retention time [10].

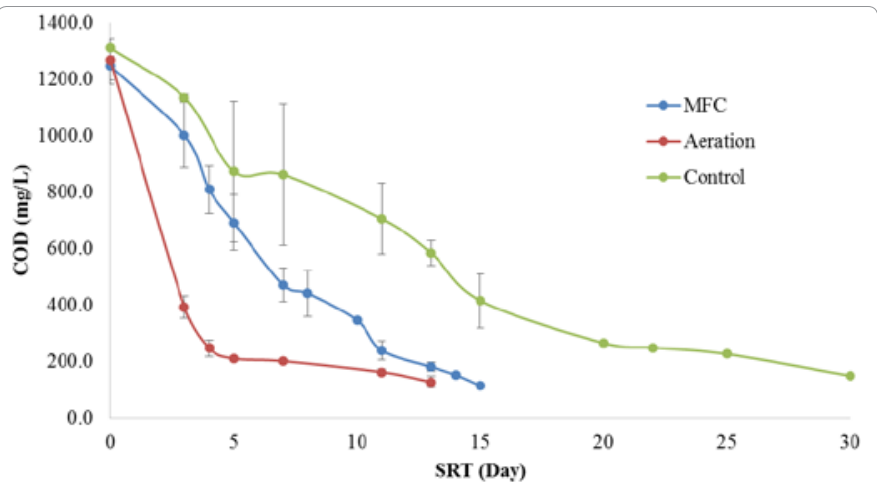

Figure 2: Comparison of COD removal efficiency between MF C, aeration, and control reactors.
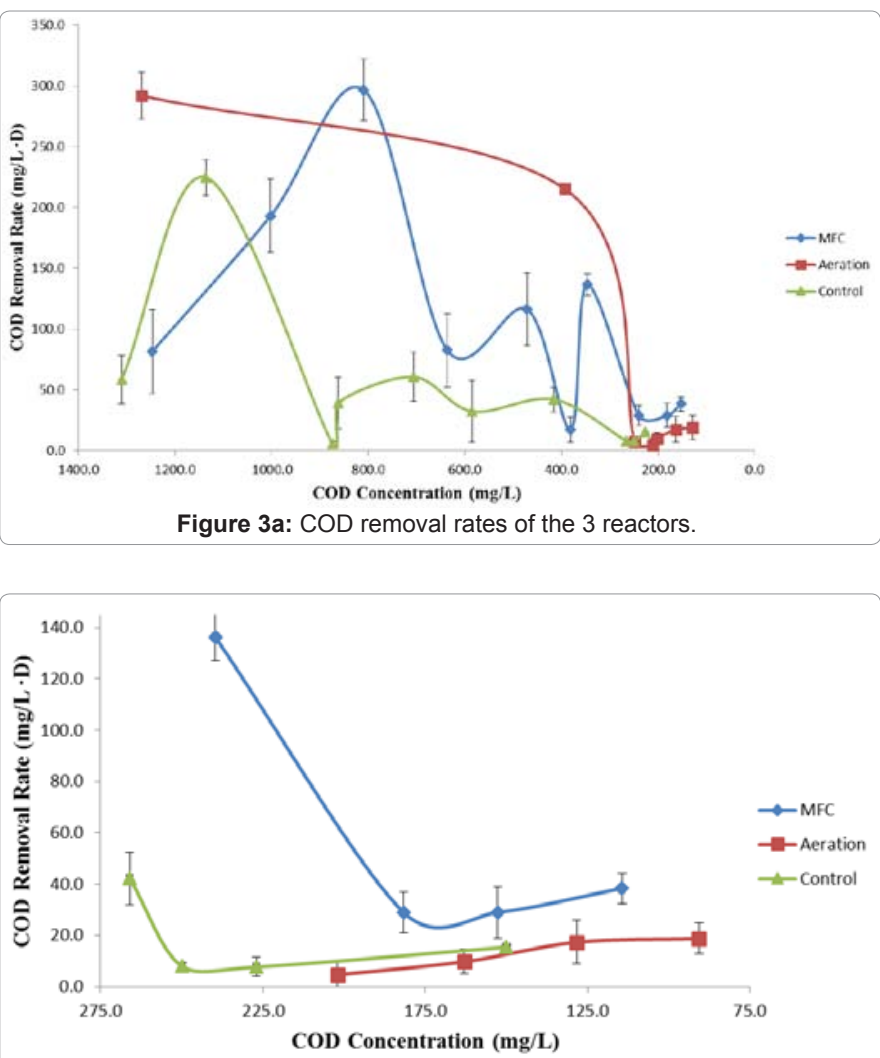

Figure 3b: COD removal rate at COD concentrations less than $275 \mathrm{mg} / \mathrm{L}$.

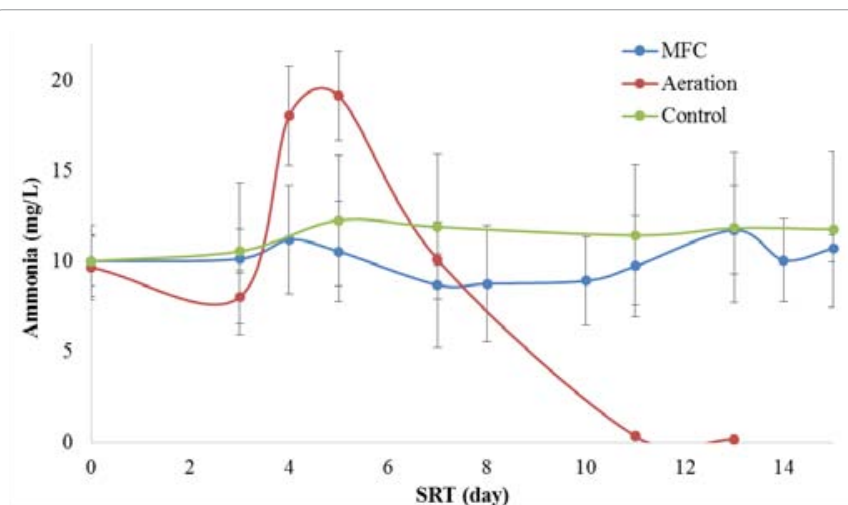

Figure 4a: Ammonia removal between the MFC, aeration, and control reactors.

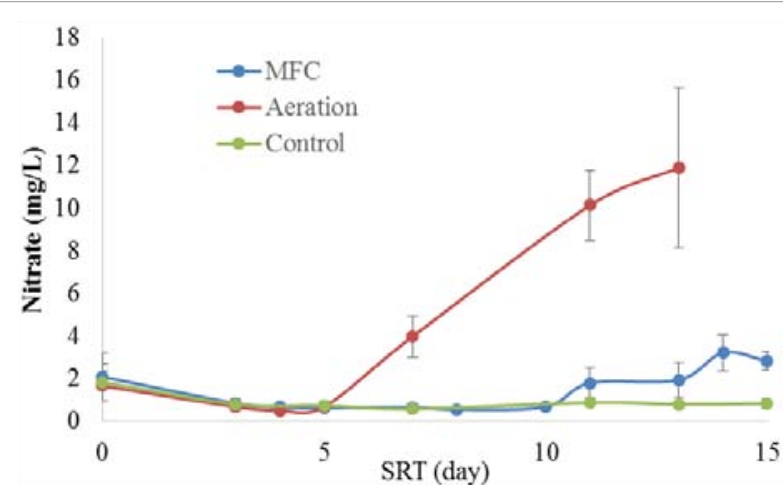

Figure 4b: Nitrate removal between the MFC, aeration, and control reactors.

\section{Ammonia and nitrate removal efficiencies}

Because the same wastewater was used as the influent for all 3 reactors, all systems were fed with the same ammonia concentration of $10 \mathrm{mg} / \mathrm{L}$. However, because the aeration reactor provided a completely aerobic environment for nitrification, it showed nearly $100 \%$ ammonia removal within 11 days, after an initial concentration increase due to organic ammonification (Figure 4a). This nitrification process is also confirmed by the accumulation of nitrate in the aeration reactor, where the increase of nitrate concentration from $2 \mathrm{mg} / \mathrm{L}$ to $12 \mathrm{mg} / \mathrm{L}$ perfectly accompanied the ammonia decrease (Figure 4b). No denitrification was observed in the aeration reactor due to the highly aerobic environment. In contrast, neither MFC or control reactor showed significant ammonia removal or nitrate accumulation during the operation, presumably due to inhibition of nitrification in the anoxic to anaerobic condition in such reactors. However, other studies have shown that MFC, supplemented with nitrate, experienced $94.1 \pm 0.9 \%$ nitrogen removal [14]. Our MFC reactor did show a slight nitrification process after 14 days of operation, as shown in Figure 4, but we had to change the solution at the time because the reactor had reached the $90 \%$ organic removal threshold.

\section{Solid production}

Preliminary characterization on total suspended solid (TSS) at different solid retention time shows that the aeration reactor produced much more solids than the other 2 reactors. The final TSS concentration from the aeration reactor was $202 \pm 50 \mathrm{mg} / \mathrm{L}$ in the reactor, at the corresponding SRT of 13 days. By comparison, the MFC 
Citation: Huggins T, Fallgren PH, Jin S, Ren ZJ (2013) Energy and Performance Comparison of Microbial Fuel Cell and Conventional Aeration Treating of Wastewater. J Microb Biochem Technol S6: 002. doi:10.4172/1948-5948.S6-002

reactor maintained the lowest TSS concentration, with $20 \pm 10 \mathrm{mg} / \mathrm{L}$, and the control reactor had a TSS of $45 \pm 10 \mathrm{mg} / \mathrm{L}$ (Figure 5). The low TSS concentration in the MFC reactor can be attributed to two reasons. First, the MFC is a biofilm based system, and the accumulation of biomass mainly resides on the electrode except of occasional biofilm falloff, so the suspended solid is low. Another reason is due to the low cell yield of the anoxic to anaerobic microorganisms in the MFC compared to the activated sludge. This finding confirms that sludge reduction can be a main benefit of MFC to replace activated sludge, and reduce plant operation cost by $20-30 \%$. When converting aeration basin into an MFC system, second clarifiers may be reduced in size, converted to solid contact basin, or even eliminated due to the reduced biomass generation [15].

\section{MFC electricity production using wastewater as the substrate}

The MFC reactor was operated under a $10 \Omega$ external resistance during operation. Low resistance was used in this study because under this condition more electrons can be transferred freely and substrate degradation can be maximized [16]. The MFC generated a maximum output voltage of $135 \mathrm{mV}$ and a current density of $193 \mathrm{~mA} / \mathrm{m}^{2}$. The total MFC power output during a 15-day SRT was $0.36 \mathrm{Wh}$, equivalent to 0.32 $\mathrm{Wh} / \mathrm{g} \mathrm{COD} / \mathrm{L}$, or $24 \mathrm{Wh}$ per cubic meter wastewater treated. With an average SRT of 13 days, the aeration reactor consumed approximately $624 \mathrm{Wh}$ of electricity, which transfers to about $547 \mathrm{Wh} / \mathrm{g} \mathrm{COD} / \mathrm{L}$. The aeration pump could have been more efficient and adjusted to aerate less during lower levels of COD, however, it was maintained as the same level in order to allow for complete nitrification and ensure oxygen was not the limiting factor. Figure 6 shows a comparison between

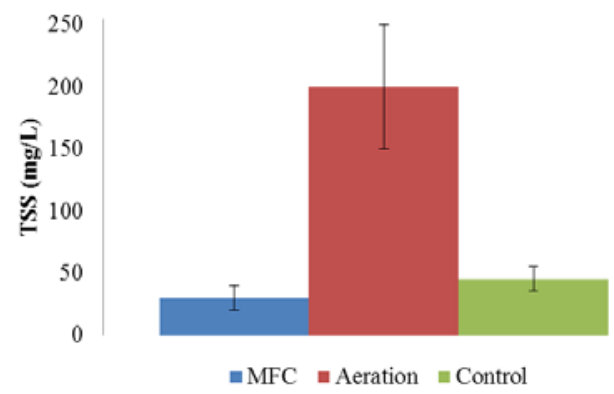

Figure 5: Final TSS concentration comparison between the MFC, aeration, and control reactors.

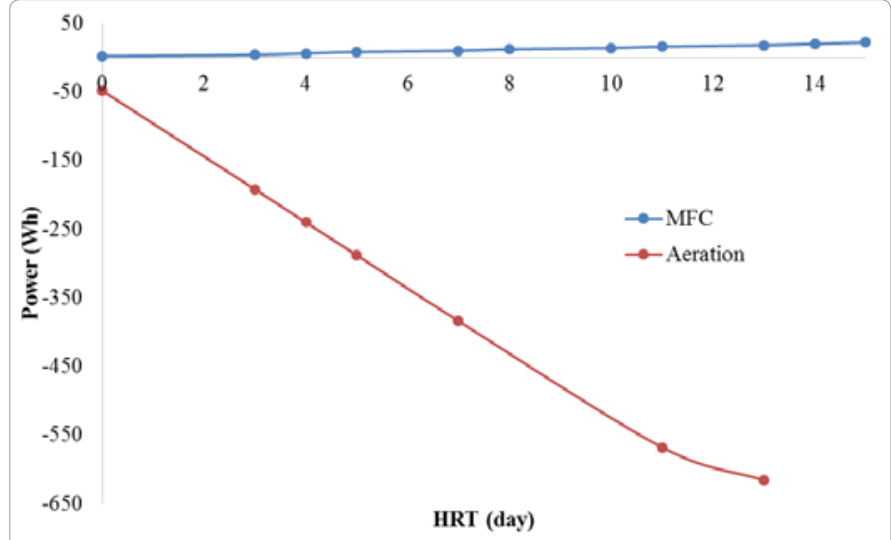

Figure 6: Power analysis for the MFC and aeration reactors. power consumption in the aeration reactor and energy saving, and production in the MFC reactor. Though this MFC was mainly designed for COD removal not for high power production, it still saves $100 \%$ of the aeration energy and produce extra energy while achieving the same treatment goal. Due to the high energy consumption of aeration in this study, it is not representative to directly calculate how much percentage of extra energy can be produced from MFC, but based on many other studies, MFC may produce $10 \%$ of extra electricity on top of aeration energy savings, if the aeration energy consumption is assumed as $1 \mathrm{kWh} / \mathrm{kg}$-COD [15].

\section{Conclusion}

The results in this study showed that microbial fuel cell can be a viable technology to treat wastewater at the same level as traditional aeration process does, and it carries great potential as an energy positive process, because it saves $100 \%$ of aeration energy with extra electricity output. It also significantly reduces sludge production, which may reduce the size of secondary clarifier and save the cost of sludge disposal.

\section{Acknowledgements}

This work was partially supported by the Bill and Melinda Gates Foundation's Grand Challenges Explorations Grant OPP1043362.

\section{References}

1. US EPA (2008) Clean watersheds needs survey overview.

2. McCarty PL, Bae J, Kim J (2011) Domestic wastewater treatment as a net energy producer--can this be achieved? Environ Sci Technol 45: 7100-7106.

3. Oh ST, Kim JR, Premier GC, Lee TH, Kim C, et al. (2010) Sustainable wastewater treatment: how might microbial fuel cells contribute. Biotechnol Adv 28: 871-881.

4. Logan BE (2009) Exoelectrogenic bacteria that power microbial fuel cells. Nat Rev Microbiol 7: 375-381.

5. Pant D, Van Bogaert G, Diels L, Vanbroekhoven K (2010) A review of the substrates used in microbial fuel cells (MFCs) for sustainable energy production. Bioresour Technol 101: 1533-1543.

6. Min B, Kim J, Oh S, Regan JM, Logan BE (2005) Electricity generation from swine wastewater using microbial fuel cells. Water Res 39: 4961-4968.

7. Feng $Y$, Wang $X$, Logan $B E$, Lee $H$ (2008) Brewery wastewater treatment using air-cathode microbial fuel cells. Appl Microbiol Biotechnol 78: 873-880.

8. Huang L, Logan BE (2008) Electricity generation and treatment of paper recycling wastewater using a microbial fuel cell. Appl Microbiol Biotechnol 80 349-355.

9. Logan BE, Regan JM (2006) Electricity-producing bacterial communities in microbial fuel cells. Trends Microbiol 14: 512-518.

10. McCarty PL, Rittmann BE (2001) Environmentral biotechnology: Principles and applications. McGraw-Hill, New York, USA.

11. Zhang F, Ge Z, Grimaud J, Hurst J, He Z (2013) Long-term performance of liter-scale microbial fuel cells treating primary effluent installed in a municipal wastewater treatment facility. Environ Sci Technol 47: 4941-4948.

12. Zhang F, Ge Z, Grimaud J, Hurst J, He Z (2013) In situ investigation of tubular microbial fuel cells deployed in an aeration tank at a municipal wastewater treatment plant. Bioresour Technol 136: 316-321.

13. Velvizhi G, Mohan SV (2011) Biocatalyst behavior under self-induced electrogenic microenvironment in comparison with anaerobic treatment evaluation with pharmaceutical wastewater for multi-pollutant removal Bioresour Technol 102: 10784-10793.

14. Virdis B, Rabaey K, Rozendal RA, Yuan Z, Keller J (2010) Simultaneous 
Citation: Huggins T, Fallgren PH, Jin S, Ren ZJ (2013) Energy and Performance Comparison of Microbial Fuel Cell and Conventional Aeration Treating of Wastewater. J Microb Biochem Technol S6: 002. doi:10.4172/1948-5948.S6-002

Page 5 of 5

nitrification, denitrification and carbon removal in microbial fuel cells. Water Res 44: $2970-2980$

15. Logan BE (2008) Microbial fuel cells. John Wiley and Sons Inc, Hoboken, New Jersey, USA.
16. Ren Z, Yan H, Wang W, Mench MM, Regan JM (2011) Characterization of microbial fuel cells at microbially and electrochemically meaningful time scales. Environ Sci Technol 45: 2435-2441.

\footnotetext{
This article was originally published in a special issue, Biofuel Cells and Bioelectrochemical Systems handled by Editor(s). Abhijeet P Borole, Oak Ridge National Laboratory, USA; Justin C Biffinger, US Naval Research
} Laboratory, USA 